\title{
Errors in greenhouse forcing and soil carbon sequestration estimates in freshwater wetlands: a comment on Mitsch et al. (2013)
}

\author{
Scott D. Bridgham • Tim R. Moore • \\ Curtis J. Richardson $\cdot$ Nigel T. Roulet
}

Received: 26 February 2014 / Accepted: 30 June 2014 / Published online: 16 July 2014

(C) Springer Science+Business Media Dordrecht 2014

\begin{abstract}
Radiative forcing feedbacks from wetlands have been an important component of past climate change and will likely be so in the future, so accurately assessing the carbon (C) and radiative balances of wetlands remains an important research priority. This commentary shows that the paper by Mitsch et al. (Landscape Ecol 28:583-597, 2013) seriously underestimated the radiative forcing effect of methane $\left(\mathrm{CH}_{4}\right)$ emissions and overestimated soil $\mathrm{C}$ sequestration in freshwater wetlands. The model that they used is flawed in double counting the atmospheric decay of $\mathrm{CH}_{4}$ and incorporating a single 100 year $\mathrm{CH}_{4}$ global warming potential. They also used a small number of sites and short-term soil dating that resulted in unrealistically high soil $\mathrm{C}$ sequestration rates, ignoring decay of the entire soil $\mathrm{C}$ pool and allochthonous inputs of $\mathrm{C}$. They calculated the radiative balance instead of the radiative forcing of natural
\end{abstract}

\section{S. D. Bridgham $(\bowtie)$}

Environmental Sciences Institute and Institute for Ecology and Evolution, University of Oregon, Eugene,

OR 97403-5289, USA

e-mail: bridgham@uoregon.edu

T. R. Moore · N. T. Roulet

Department of Geography, McGill University, 805

Sherbrooke Street West, Montreal, QC H3A 0B9, Canada

\section{J. Richardson}

Duke University Wetland Center, Nicholas School of the Environment, Duke University, Levine Science Research Center, Box 90333, Durham, NC 27708-0333, USA wetlands, making their calculations irrelevant to anthropogenic climate change. Irrespective of the radiative forcing of wetlands, they provide essential ecosystem services that are important to protect.

Keywords Wetlands - Global warming potential . Radiative forcing $\cdot$ Methane $\cdot$ Soil carbon sequestration

\section{Introduction}

Management decisions in wetlands may have important consequences for global radiative forcing because of their massive soil carbon (C) pools, high methane $\left(\mathrm{CH}_{4}\right)$ emissions, and potentially high soil $\mathrm{C}$ sequestration rates (Bridgham et al. 2006). A recent article by Mitsch et al. (2013) addresses this theme by suggesting that soil $\mathrm{C}$ sequestration outweighs the warming effect of $\mathrm{CH}_{4}$ emissions in the world's wetlands within decades to few hundred years, and that globally wetlands comprise a substantial soil C sink. However, we feel that this paper has numerous inaccuracies that have important implications for management decisions. The limitations of their analysis have also been addressed by Neubauer (2014), who reanalyzed the C flux data in Mitsch et al. (2013) with the well-established Frolking et al. (2006) model of wetland radiative forcing that includes sustained $\mathrm{CH}_{4}$ emissions, five atmospheric carbon dioxide 
$\left(\mathrm{CO}_{2}\right)$ pools with different lifetimes, and a more defensible atmospheric $\mathrm{CH}_{4}$ lifetime. Neubauer also included $\mathrm{N}_{2} \mathrm{O}$ emissions in his model. He demonstrated that Mitsch et al. vastly underestimated the time required for a wetland to have a net cooling effect on the environment. While we consider the Neubauer article to be a much more appropriate estimate of wetland radiation forcing and endorse his findings, many wetland practitioners may be confused by a comparison of two models, each with its own set of assumptions. We show here that: (i) the model developed by Mitsch et al. is flawed in its conception without the need to resort to a comparison with another model, (ii) Mitsch et al. used inflated C sequestration numbers that do not represent a reasonable range of those reported in the literature, and (iii) Mitsch et al. confused the fundamental concepts of radiative forcing and radiative balance.

\section{Limitations of the Mitsch et al. model}

While we agree with (Neubauer 2014) that a model with sustained $\mathrm{CH}_{4}$ emissions more effectively captures the radiative forcing of wetlands over time, the global warming potential (GWP) concept used by Mitsch et al. is pervasive in the scientific literature as a means to compare the radiative effects of different greenhouse gases (GHG). Hence, it is important to point out that Mitsch et al. used GWPs incorrectly. This is also stated by Neubauer but without the proof that we provide here.

Mitsch et al. constructed a simple two state-variable model that we summarize in Eqs. 1-3:

$$
\begin{aligned}
& d M_{\mathrm{CH}_{4} / d t}=F_{\mathrm{CH}_{4}}-k_{\mathrm{CH}_{4}} M_{\mathrm{CH}_{4}} \\
& d M_{\mathrm{CO}_{2} / d t}=k_{\mathrm{CH}_{4}} M_{\mathrm{CH}_{4}}-F_{\mathrm{CO}_{2}}
\end{aligned}
$$

where $\mathrm{M}_{\mathrm{CH}_{4}}$ and $\mathrm{M}_{\mathrm{CO}_{2}}$ are the atmospheric masses of wetland-derived $\mathrm{CH}_{4}$ and $\mathrm{CO}_{2}$, respectively (units of g C m$\left.{ }^{-2}\right) ; F_{\mathrm{CH}_{4}}$ and $\mathrm{F}_{\mathrm{CO}_{2}}$ are the net fluxes of $\mathrm{CH}_{4}$ and $\mathrm{CO}_{2}$ from or into the wetland; and $k_{\mathrm{CH}_{4}}$ is the firstorder decay of $\mathrm{CH}_{4}$ in the atmosphere. The $\mathrm{k}_{\mathrm{CH}_{4}} \mathrm{M}_{\mathrm{CH}_{4}}$ term represents the oxidation of $\mathrm{CH}_{4}$ to $\mathrm{CO}_{2}$ in the atmosphere. Mitsch et al. then defined a total forcing from the wetland in $\mathrm{CO}_{2}$ equivalents $\left(\mathrm{CO}_{2 e q}\right)$ at any point over 100 years as:

$$
C O_{2 e q}(t)=M_{C O_{2}}(t)+\left(G W P_{C H_{4}} \times M_{C H_{4}}(t)\right)
$$

where $\mathrm{GWP}_{\mathrm{CH}_{4}}$ is the global warming potential of $\mathrm{CH}_{4}$ at 100 years (i.e., 25).

However, use of GWP in this manner is fraught with problems. $\mathrm{GWP}_{\mathrm{CH}_{4}}$ is represented mathematically as a $1 \mathrm{~kg}$ pulse emission of $\mathrm{CH}_{4}$ relative to a $1 \mathrm{~kg}$ pulse emission of $\mathrm{CO}_{2}$ over some time horizon $\mathrm{TH}$ (Forster et al. 2007):

$$
G W P_{C_{4}}=\frac{\int_{0}^{T H} R F_{C H_{4}}(t) d t}{\int_{0}^{T H} R F_{C O_{2}}(t) d t}=\frac{\int_{0}^{T H} a_{C_{4}}\left[M_{C_{4}}(t)\right] d t}{\int_{0}^{T H} a_{C O_{2}}\left[M_{C O_{2}}(t)\right] d t}
$$

where $R F$ is the radiative forcing and $a$ is the instantaneous radiative forcing due to a unit increase of the gas in the atmosphere (i.e., radiative efficiency). One can easily see in Eq. 4 that the change in $\mathrm{M}_{\mathrm{CH}_{4}}$ over time is already incorporated into the GWP, so by using it in Eq. 3 Mitsch et al. doubled counted for the atmospheric decay of $\mathrm{CH}_{4}$ and seriously underestimated the radiative forcing of wetlands.

The instantaneous radiative efficiency of $\mathrm{CH}_{4}$ $\left(\mathrm{a}_{\mathrm{CH}_{4}}\right)$ is 73 times greater than that for $\mathrm{CO}_{2}\left(a_{\mathrm{CO}_{2}}\right)$ on a mass basis (Forster et al. 2007), but this difference decreases through time because the atmospheric lifetime of $\mathrm{CH}_{4}$ in the atmosphere is much shorter than $\mathrm{CO}_{2}$. Thus, the GWP of a pulse of $\mathrm{CH}_{4}$ emitted from a wetland is initially 73 , at 20 years it is still 72 , and at 100 years it is 25 . Consequently, using a 100 year pulse-based GWP for $\mathrm{CH}_{4}$ in a model of continuous $\mathrm{CO}_{2}$ and $\mathrm{CH}_{4}$ fluxes over a 100 years simulation as done by Mitsch et al. is incorrect because the majority of the $\mathrm{CH}_{4}$ emitted over that period would have a much higher GWP. In summary, it is clear that the model of Mitsch et al. vastly underestimated the radiative forcing of $\mathrm{CH}_{4}$ emissions from wetlands, as is shown above and by Neubauer (2014) in his reanalysis of their data using a more appropriate model.

\section{Mitsch et al. overestimate wetland soil $\mathrm{C}$ sequestration}

Mitsch et al. determined soil $\mathrm{C}$ sequestration with ${ }^{137} \mathrm{Cs}$ and ${ }^{210} \mathrm{~Pb}$ dating, which are common techniques to quantify soil $\mathrm{C}$ sequestration over roughly the past 50-100 years. However, all peatlands and most 
Table 1 A comparison of world freshwater wetland net $\mathrm{C}$ sequestration estimates

\begin{tabular}{|c|c|c|c|c|c|c|}
\hline & \multicolumn{3}{|l|}{ Mitsch et al. (2013) } & \multicolumn{3}{|l|}{ This study } \\
\hline & Mineral soil wetlands ${ }^{\mathrm{a}}$ & Boreal peatlands & $\begin{array}{l}\text { Total or } \\
\text { weighted } \\
\text { average }\end{array}$ & $\begin{array}{l}\text { Mineral-soil } \\
\text { wetlands }\end{array}$ & $\begin{array}{l}\text { Boreal } \\
\text { peatlands }\end{array}$ & $\begin{array}{l}\text { Total or } \\
\text { weighted } \\
\text { average }\end{array}$ \\
\hline Net $\mathrm{C}$ retention $\left(\mathrm{g} \mathrm{C} \mathrm{m}^{-2}\right.$ year $\left.^{-1}\right)$ & 208 & 29 & 118 & $17^{\mathrm{b}}$ & $10.4^{\mathrm{c}}$ & 13.7 \\
\hline Wetland area $\times 10^{6} \mathrm{~km}^{2}$ & 3.5 & 3.5 & 7.0 & 3.5 & 3.5 & 7.0 \\
\hline Total $\mathrm{C}$ retention $\left(\times 10^{12} \mathrm{~g} \mathrm{C}\right.$ year $\left.^{-1}\right)$ & 720 & 110 & 830 & 60 & 36 & 96 \\
\hline
\end{tabular}

${ }^{a}$ Includes the sum or weighted average of tropical and sub-tropical, and temperate wetlands in (Mitsch et al. 2013)

b From Bridgham et al. (2006)

c Net C balance during the last millennium from $\mathrm{Yu}(2012)$

mineral-soil wetlands have been accumulating soil $\mathrm{C}$ for centuries to millennia, and that older soil $\mathrm{C}$ continues to undergo slow decomposition, necessitating longer term dating techniques like ${ }^{14} \mathrm{C}$ to accurately estimate whole-profile soil $\mathrm{C}$ sequestration rates. Indeed, rates of soil $\mathrm{C}$ sequestration based on ${ }^{14} \mathrm{C}$ systematically give rates $\sim 20 \%$ of short-term measurements (either ${ }^{137} \mathrm{Cs}$ or ${ }^{210} \mathrm{~Pb}$ ) under constant accumulation conditions (Craft and Richardson 1998; Turunen et al. 2004). Thus, the sequestration values of $194 \pm 56 \mathrm{~g} \mathrm{C} \mathrm{m}^{-2}$ year $^{-1}$ for tropical wetlands and $278 \pm 42 \mathrm{~g} \mathrm{C} \mathrm{m}^{-2}$ year $^{-1}$ for temperate wetlands used by Mitsch et al. in their global extrapolation only reflect short-term apparent rates of $\mathrm{C}$ accumulation but do not take into account decomposition of older $\mathrm{C}$ and are likely much larger than whole-profile soil $\mathrm{C}$ sequestration rates. Also, all soil $\mathrm{C}$ sequestration estimates using dating techniques give a constant value over the time frame of reference and do not reflect the current rate, which may vary substantially over time in human-impacted systems.

Even the short-term $\mathrm{C}$ sequestration estimates used by Mitsch et al. are much higher than those reported in a review of rates from 26 North American mineral-soil wetlands (Bridgham et al. 2006). They found that soil $\mathrm{C}$ sequestration rates ranged from 0 to $616 \mathrm{~g} \mathrm{C} \mathrm{m}^{-2}$ year $^{-1}$, with this large range probably reflecting the dating method used (as discussed above) and natural variability. The geometric mean of $17 \mathrm{~g} \mathrm{C} \mathrm{m}^{-2}$ year ${ }^{-1}$ was deemed to be the most reliable value. As explained in Bridgham et al. (2006), even this lower value is probably an overestimate because much of the $\mathrm{C}$ stored in mineral-soil wetlands may be allochthonous (i.e., derived from outside the wetland) versus autochthonous (derived from within the wetland). The net accumulation of allochthonous $\mathrm{C}$ within a wetland at a landscape scale is solely dependent upon the rate of replacement of soil $\mathrm{C}$ in the upland source and the fractional decomposition of the allochthonous C within the wetland (Van Oost et al. 2007), although these calculations are almost never done in practice.

In contrast to mineral-soil wetlands, $\mathrm{C}$ in peatlands is almost entirely autochthonous, and long-term soil $\mathrm{C}$ sequestration (using basal and other ${ }^{14} \mathrm{C}$ dates) has been intensively studied. Based upon long-term $\mathrm{C}$ accumulation data reported in the literature, Bridgham et al. (2006) estimated that permafrost peatlands sequester $13 \mathrm{~g} \mathrm{C} \mathrm{m}^{-2}$ year $^{-1}$ and non-permafrost northern peatlands sequester $19 \mathrm{~g} \mathrm{C} \mathrm{m}^{-2}$ year $^{-1}$, which is comparable to a recent estimate of $19 \mathrm{~g}$ $\mathrm{C} \mathrm{m}^{-2}$ year $^{-1}$ for all northern peatlands ( $\mathrm{Yu}$ et al. 2010). These values are averaged over the entire peat profile, but an approach using ${ }^{14} \mathrm{C}$ dates through the entire peat profile and considering long-term decomposition for 33 sites estimated a net $\mathrm{C}$ balance of $10 \mathrm{~g} \mathrm{C} \mathrm{m}^{-2}$ year $^{-1}$ in northern peatlands over the last millennium (Yu 2012). In comparison, Mitsch et al. give a somewhat higher soil sequestration value of $29 \pm 13 \mathrm{~g} \mathrm{C} \mathrm{m}^{-2}$ year $^{-1}$ for boreal peatlands that is still within the error bounds of previous estimates.

We next use the wetland areas in Mitsch et al. and our more realistic estimates of soil $\mathrm{C}$ sequestration rates to compare our values of global soil $\mathrm{C}$ retention in freshwater wetlands to those of Mitsch et al. (Table 1). We estimate that mineral-soil wetlands globally sequester $60 \mathrm{Tg} \mathrm{C}$ year $^{-1}$ and boreal peatlands sequester $36 \mathrm{Tg} \mathrm{C}$ year $^{-1}\left(1 \mathrm{Tg}=10^{12} \mathrm{~g}\right)$, for a global total of $96 \mathrm{Tg} \mathrm{C}$ year $^{-1}$. Comparatively, Mitsch et al. estimate that mineral-soil wetlands sequester $720 \mathrm{Tg} \mathrm{C}_{\text {year }}{ }^{-1}$ and peatlands sequester $110 \mathrm{Tg} \mathrm{C}$ year ${ }^{-1}$, for a total of 
$830 \mathrm{Tg} \mathrm{C}$ year $^{-1}$ - a value 8.6 times higher than ours. Because most of the difference in these estimates is attributed to mineral-soil wetlands, it is useful to make a reality check of the soil $\mathrm{C}$ sequestration numbers in Mitsch et al. A sequestration rate of $278 \mathrm{~g} \mathrm{C} \mathrm{m}^{-2}$ year $^{-1}$ as reported for temperate mineral-soil wetlands results in an accretion rate of $0.36 \mathrm{~cm}_{\text {year }}^{-1}$, assuming $7.7 \%$ soil C and a bulk density of $1.0 \mathrm{~g} \mathrm{~cm}^{-3}$ (Batjes 1996; Smith et al. 2001). While undoubtedly some wetlands experience such high sedimentation rates in areas of high erosion over some period of time (e.g., Craft and Casey 2000), global wetlands would become uplands over centuries to millennia at this high sedimentation rate, which clearly has not happened.

While accurate estimates of $\mathrm{C}$ sequestration are difficult to obtain, what is clear is that Mitsch et al.'s soil $\mathrm{C}$ sequestration rates are from only a handful of sites and almost certainly severely overestimate $\mathrm{C}$ sequestration, especially when extrapolated to the global scale.

\section{Mitsch et al. inappropriately used radiation balance instead of radiative forcing}

Mitsch et al. use the term 'radiative forcing' but actually calculate the radiative balance of most of their study wetlands. Confusion about the seemingly subtle distinction between these two terms is widespread and by no means limited to Mitsch et al., but it actually has far-reaching implications for considering the role of wetlands in climate change (Bridgham et al. 2006). Radiative balance refers to the static radiative effect of GHG, whereas the radiative forcing refers to an externally (usually human) imposed perturbation on the Earth's radiative energy budget (Ramaswamy et al. 2001), i.e. it is the calculation of the perturbation relative to a quasi steady-state balance. Examining static rates of these processes in natural wetlands is relevant to anthropogenic climate change only as a baseline unless it can be shown that those rates have changed due to human activities, either directly or indirectly. Of the wetlands in the Mitsch et al. study, their analysis was demonstrably relevant to radiative forcing in only the two restored wetlands in Ohio. Mitsch et al. did correctly acknowledge this distinction in their sentence "We also showed created wetlands had $\mathrm{CH}_{4}$ emissions lower than or comparable to natural wetlands after 13-15 years." However, in this case they extrapolated from two restored wetlands at a single site to all restored wetlands, which we consider inappropriate evidence for this broad statement.

\section{Conclusions}

Mitsch et al. use a flawed model to calculate the radiative balance of freshwater wetlands that seriously underestimated the radiative forcing effect of wetland $\mathrm{CH}_{4}$ emissions. They also likely greatly overestimated wetland soil $\mathrm{C}$ sequestration rates. Moreover, they calculated the radiative balance instead of the radiative forcing of natural wetlands, and thus their global calculations are invalid with respect to the role of wetlands in climate change. When considered from their initiation, most freshwater wetlands should eventually have a net radiative cooling effect, but this may take centuries to millennia to occur (Frolking et al. 2006; Neubauer 2014). However, marine-associated wetlands often have quite high soil $\mathrm{C}$ sequestration rates (Pendleton et al. 2012) and low $\mathrm{CH}_{4}$ emissions (Bridgham et al. 2006), although many of the problems identified here in accurately assessing soil $\mathrm{C}$ sequestration rates in freshwater wetlands also apply to marine-associated wetlands. Additionally, forested wetlands can sequester large amounts of $\mathrm{C}$ in tree biomass (Mitsch and Gosselink 2000; Bridgham et al. 2006), and many have water tables that are far below the surface for extended periods during the growing season (Mitsch and Gosselink 2000), which should reduce $\mathrm{CH}_{4}$ emissions. Thus, restoration or creation of marine-associated and forested wetlands may quite rapidly lead to a negative (i.e., cooling) radiative forcing. Importantly, peatlands comprise a huge global C pool (Bridgham et al. 2006; Yu 2012) that is critically important to protect because oxidation of that resource due to drainage will likely lead to a large positive radiative forcing, even after accounting for reduction in $\mathrm{CH}_{4}$ emissions. Abundant evidence suggests that wetlands were an important driver of past glacial/interglacial cycles (Chappellaz et al. 1993a, b; Blunier et al. 1995; Loulergue et al. 2008) and will likely remain an important feedback to future anthropogenic climate change. For all of these reasons, accurately assessing the $\mathrm{C}$ and radiative balances of wetlands remains an important research priority. Moreover, we strongly agree with the conclusion of Mitsch et al. that "Because wetlands provide many 
ecosystem services in addition to $\mathrm{C}$ sequestration, it is shortsighted to suggest that wetlands should not be created or restored because of their [GHG] emissions."

Acknowledgments The comments of J. Patrick Megonigal, the associate editor, and two anonymous reviewers greatly improved this manuscript.

\section{References}

Batjes NH (1996) Total carbon and nitrogen in the soils of the world. Eur J Soil Sci 47:151-163

Blunier T, Chappellaz J, Schwander J, Stauffer B, Raynaud D (1995) Variations in atmospheric methane concentration during the Holocene epoch. Nature 374:46-49

Bridgham SD, Megonigal JP, Keller JK, Bliss NB, Trettin C (2006) The carbon balance of North American wetlands. Wetlands 26:889-916

Chappellaz J, Bluniert T, Raynaud D, Barnola JM, Schwander J, Stauffert B (1993a) Synchronous changes in atmospheric $\mathrm{CH}_{4}$ and Greenland climate between 40 and $8 \mathrm{kyr}$ BP. Nature 366:443-445

Chappellaz JA, Fung IY, Thompson AM (1993b) The atmospheric $\mathrm{CH}_{4}$ increase since the Last Glacial Maximum. Tellus B 45:228-241

Craft CB, Casey WP (2000) Sediment and nutrient accumulation in floodplain and depressional freshwater wetlands of Georgia, USA. Wetlands 20:323-332

Craft CB, Richardson CJ (1998) Recent and long-term organic soil accretion and nutrient accumulation in the Everglades. Soil Sci Soc Am J 62:834-843

Forster P, Ramaswamy P, Artaxo P, Berntsen T, Betts R, Fahey DW, Haywood J, Lean J, Lowe DC, Myhre G, Nganga J, Prinn R, Raga G, Schulz M, Van Dorland R (2007) Changes in atmospheric constituents and in radiative forcing. In: Solomon S, Qin D, Manning M, Chen Z, Marquis M, Averyt KB, Tignor M, Miller HL (eds) Climate change 2007: the physical science basis. Contribution of working group I to the fourth assessment report of the intergovernmental panel on climate change. Cambridge University Press, Cambridge, pp 129-234

Frolking S, Roulet N, Fuglestvedt J (2006) How northern peatlands influence the earth's radiative budget: sustained methane emission versus sustained carbon sequestration. J Geophys Res 111:G01008. doi:10.1029/2005JG000091
Loulergue L, Schilt A, Spahni R, Masson-Delmotte V, Blunier T, Lemieux B, Barnola JM, Raynaud D, Stocker TF, Chappellaz J (2008) Orbital and millennial-scale features of atmospheric $\mathrm{CH}_{4}$ over the past 800,000 years. Nature 453:383-386

Mitsch WJ, Bernal B, Nahlik AM, Mander Ü, Zhang L, Anderson CJ, Jørgensen SE, Brix H (2013) Wetlands, carbon, and climate change. Landscape Ecol 28:583-597. doi:10.1007/s10980-012-9758-8

Mitsch WJ, Gosselink JG (2000) Wetlands. Wiley, New York

Neubauer SC (2014) On the challenges of modeling the net radiative forcing of wetlands: reconsidering Mitsch et al. (2013). Landscape Ecol 29:571-577. doi:10.1007/s10980014-9986-1

Pendleton L, Donato DC, Murray BC, Crooks S, Jenkins WA, Sifleet S, Craft C, Fourqurean JW, Kauffman JB, Marbà N, Megonigal P, Pidgeon E, Herr D, Gordon D, Baldera A (2012) Estimating global "blue carbon" emissions from conversion and degradation of vegetated coastal ecosystems. PLoS One 7:e43542. doi:10.1371/journal.pone. 0043542

Ramaswamy V, Boucher O, Haigh J, Hauglustaine D, Haywood J, Myhre G, Nakajima T, Shi GY, Solomon S (2001) Radiative forcing of climate change. In: Houghton JT, Ding Y, Griggs DJ, Noguer M, van der Linden PJ, Dai X, Maskell K, Johnson CA (eds) Climate change 2001: the scientific basis. Contribution of working group I to the third assessment report of the intergovernmental panel on climate change. Cambridge University Press, Cambridge, pp 349-416

Smith SV, Renwick WH, Buddemeier RW, Crossland CJ (2001) Budgets of soil erosion and deposition for sediments and sedimentary organic carbon across the conterminous United States. Global Biogeochem Cycles 15:697-707

Turunen J, Roulet NT, Moore TR (2004) Nitrogen deposition and increased carbon accumulation in ombrotrophic peatlands in eastern Canada. Glob Biogeochem Cycles 18:GB3002, doi:10.1029/2003GB002154

Van Oost K, Quine TA, Govers G, De Gryze S, Six J, Harden JW, Ritchie JC, McCarty GW, Heckrath G, Kosmas C, Giraldez JV, da Silva JRM, Merckx R (2007) The impact of agricultural soil erosion on the global carbon cycle. Science 318:626-629. doi:10.1126/science.1145724

Yu ZC (2012) Northern peatland carbon stocks and dynamics: a review. Biogeosciences 9:4071-4085. doi:10.5194/bg-94071-2012

Yu Z, Loisel J, Brosseau DP, Beilman DW, Hunt SJ (2010) Global peatland dynamics since the Last Glacial Maximum. Geophys Res Lett 37:L13402. doi:10.1029/2010g1043584 
Reproduced with permission of the copyright owner. Further reproduction prohibited without permission. 